\title{
Selective degradation of maternal and embryonic transcripts in in vitro produced bovine oocytes and embryos using sequence specific double-stranded RNA
}

\author{
Korakot Nganvongpanit, Heike Müller, Franca Rings, Michael Hoelker, Danyel Jennen, \\ Ernst Tholen, Vitezslav Havlicek ${ }^{1}$, Urban Besenfelder ${ }^{1}$, Karl Schellander and Dawit Tesfaye \\ Institute of Animal Science, Animal Breeding and Husbandry Group, University of Bonn, Endenicher Allee 15, \\ 53115, Bonn, Germany and ${ }^{1}$ University of Veterinary Medicine Vienna, Veterinär platz 1, A-1210, Vienna, Austria
}

Correspondence should be addressed to D Tesfaye; Email: tesfaye@itz.uni-bonn.de

\begin{abstract}
RNA interference (RNAi) has been used for selective degradation of an mRNA transcript or inhibiting its translation to a functional protein in various species. Here, we applied the RNAi approach to suppress the expression of the maternal transcript C-mos and embryonic transcripts Oct-4 in bovine oocytes and embryos respectively, using microinjection of sequence-specific double-stranded RNA (dsRNA). For this, 435 bp C-mos and 341 bp Oct-4 dsRNA were synthesized and microinjected into the cytoplasm of immature oocytes and zygotes respectively. In experiment 1 , immature oocytes were categorized into three groups: those injected with C-mos dsRNA, RNase-free water and uninjected controls. In experiment 2, in vitro produced zygotes were categorized into three groups: those injected with Oct-4 dsRNA, RNase-free water and uninjected controls. The developmental phenotypes, the level of mRNA and protein expression were investigated after treatment in both experiments. Microinjection of C-mos dsRNA has resulted in $\mathbf{7 0} \%$ reduction of C-mos transcript after maturation compared to the water-injected and uninjected controls $(P<0.01)$. Microinjection of zygotes with Oct-4 dsRNA has resulted in $72 \%$ reduction in transcript abundance at the blastocyst stage compared to the uninjected control zygotes $(P<0.01)$. Moreover, a significant reduction in the number of inner cell mass (ICM) cells was observed in Oct-4 dsRNA-injected embryos compared to the other groups. From oocytes injected with C-mos dsRNA, $60 \%$ showed the extrusion of the first polar body compared to $50 \%$ in water-injected and $44 \%$ in uninjected controls. Moreover, only oocytes injected with C-mos dsRNA showed spontaneous activation. In conclusion, our results demonstrated that sequence-specific dsRNA can be used to knockdown maternal or embryonic transcripts in bovine embryogenesis.

Reproduction (2006) 131 861-874
\end{abstract}

\section{Introduction}

Presently, the genomes of various species including the bovine are largely sequenced. Moreover, several studies have been carried out during the last decade to investigate the expression patterns of genes in bovine embryogenesis in response to the various culture and treatment conditions (Rizos et al. 2002, 2003, Lonergan et al. 2003a, 2003b, Tesfaye et al. 2004, El-Halawany et al. 2005). Despite this fact, the function of a large number of genes in mammalian embryogenesis is not yet investigated or not known. Transgenic and gene-targeted mouse lines have been used extensively to study the function of various genes in mammalian embryogenesis. These mouse knockout studies are relatively slow and this tool cannot keep pace with the rapid accumulation of new sequence information produced by the various genome projects. Therefore, what is needed is a technique that can be used to jump directly from sequence to function in a whole animal. For this, the post-transcriptional gene silencing (PTGS) by doublestranded RNA (dsRNA) or RNA interference (RNAi) has emerged as a new tool for studying gene function in an increasing number of organisms (Fire 1999). Following its application in Caenorhabditis elegance (Fire et al. 1998), the RNAi approach by introduction of dsRNA has been used in various mammalian species such as human (Brusselmans et al. 2005, Cheng et al. 2005, Hyslop et al. 2005), mouse (Svoboda et al. 2000, Wianny \& ZernickaGoetz 2000, Grabarek et al. 2002, Ma et al. 2002, Stein et al. 2003, Alizadeh et al. 2005, Gui \& Joyce 2005, Plusa et al. 2005) and porcine (Cabot \& Prather 2003). Most recently, the work by our group (Nganvongpanit et al. 2006) and others (Paradis et al. 2005) have used 
the RNAi approach to suppress transcripts in bovine embryos and oocytes respectively. Recently, microinjection of dsRNA which interferes with genes that regulate cell polarity (Par3 and aPKC) in randomly selected blastomeres of cleavage-stage mouse embryos has enabled direction of defined cells to new positions and redirection of their fate in the preimplantation embryos (Plusa et al. 2005).

During oocyte maturation, meiotic resumption is characterised by germinal vesicle breakdown (GVBD), chromosomal condensation, progression to metaphase of the first meiosis release of the first polar body and then arrest at the metaphase of the second meiosis (MII) (Motlik \& Kubelka 1990). The meiotic arrest (MII arrest) is maintained by the persistently high activity of cyclin B-p34 cdc2 kinase, also called maturation promotion factor (MPF) (Draetta \& Beach 1988, Brizuela et al. 1989, Masui 1992, Fan \& Sun 2004). MPF activity is necessary to maintain MII arrest in oocytes and the function of a multi-component complex, known as the cytostatic factor (CSF), which is required to sustain MPF activity (Hirao \& Eppig 1997). CSF activity is the coordinated function of at least two proteins, MAP kinase (MAPK) and mos. The activation of MAPK mediates the activation of MPF, a key regulator of the $M$ phase, and results in the induction of GVBD in xenopus (Gotoh \& Nishida 1995, Kosako et al. 1996), mouse (Araki et al. 1996), bovine (Fissore et al. 1996) and porcine (Ohashi et al. 2003). Mos, the C-mos protooncogene product, is one of the central regulators of meiosis in vertebrate oocytes (Sagata 1996). Injection of mouse wild-type Mos RNA into bovine immature oocytes has induced a marked increase in the catalytic activity of MAPK and resulted in a considerable acceleration of GVBD, without affecting the ability of oocytes to progress to the MIl stage (Fissore et al. 1996).
However, so far, no clear evidence is available whether this kinase cascade in bovine is exclusively initiated by Mos or not. Inhibition of C-mos synthesis in mouse oocytes using RNAi has resulted in pathenogenetic activation (Wianny \& Zernicka-Goetz 2000), as has been observed in $\mathrm{mos}^{-1-}$ knockout mouse.

Oct-4 belongs to the sub-group of octamer-binding proteins that bind by the POU domain to the promoter and enhancer regions of various genes with octamer sites (Ovitt \& Schöler 1998). The Oct-4 gene is presumed to be involved in the maintenance of an undifferentiated state and also the determination or establishment of the germ line (Ovitt \& Schöler 1998). Moreover, Oct-4 influences several genes expressed during early development, including Fgf-4, Rex-1, Sox-2, OPN, hCG, Utf-1 (Pesce \& Schöler 2001) and INF $\tau$ (Ezashi et al. 2001). So far, the role and possible effect of C-mos and Oct-4 suppression in bovine oocytes and embryos have not yet been investigated. Therefore, here we investigated the effect of the suppression of C-mos and Oct-4 genes on the mRNA and protein expression during bovine embryogenesis. Moreover, biological effects of the suppression of these genes in oocytes and embryos will be assessed during in vitro development.

\section{Materials and Methods \\ Synthesis of DNA template}

Pairs of primers were designed according to bovine cDNA sequences found in GenBank (see Table 1 for details) using Primer Express Software v2.0 (Applied Biosystems, Foster City, CA, USA) to amplify C-mos and Oct-4 transcripts. These primers generated PCR amplicons corresponding to the coding sequence and the identity of the product was confirmed by sequencing.

Table 1 Details of primers used for dsRNA preparation and quantitative real-time PCR.

\begin{tabular}{|c|c|c|c|c|}
\hline Gene & $\begin{array}{l}\text { GenBank } \\
\text { accession no. }\end{array}$ & Primer sequences & $\begin{array}{c}\text { Annealing } \\
\text { temperature }\left({ }^{\circ} \mathrm{C}\right)\end{array}$ & $\begin{array}{l}\text { Product } \\
\text { size }(b p)\end{array}$ \\
\hline$C-m_{0 s}^{a}$ & AY630920 & $\begin{array}{l}\text { 5'-GTTCCATCGACTGGGAGCAGGT-3' } \\
\text { 5'-TGCTTTGCGCGTGGAGGAACAG-3' }\end{array}$ & 65 & 435 \\
\hline$C-\operatorname{mos}^{b}$ & AY630920 & $\begin{array}{l}5^{\prime} \text {-GGGCAATATCACCTTGCACCA-3' } \\
5^{\prime} \text {-CGCTGACCACGTCTAGGGAGTA-3' }\end{array}$ & 60 & 113 \\
\hline$C-\operatorname{mos}^{c}$ & AY630920 & $\begin{array}{l}5^{\prime} \text {-GTAATACGACTCACTATAGGGGTTCCATCGACTGGGAGCAGGT-3' } \\
5^{\prime} \text {-GTAATACGACTCACTATAGGGTGCTTTGCGCGTGGAGGAACAG-3' }\end{array}$ & & \\
\hline Fgf- $4^{b}$ & AF170490 & $\begin{array}{l}\text { 5'-GGCTCTCTGGCTTTGATCGTG-3' } \\
5^{\prime} \text {-GAACTGTCGGGCCAGAGGAA-3' }\end{array}$ & 60 & 129 \\
\hline Gdf- $9^{b}$ & NM174681 & $\begin{array}{l}\text { 5'-GATTGAGATTGATGTGACAGCTCCT-3' }^{\prime} \\
5^{\prime} \text {-TTGTCCCACTTCAGTTGACTAAAGC-3' }\end{array}$ & 60 & 471 \\
\hline Oct- $4^{\mathrm{a}, \mathrm{b}}$ & AY490804 & $\begin{array}{l}\text { 5'-CCCAGGACATCAAAGCTCTTCAG-3' } \\
5^{\prime} \text {-GAACATGCTCTCCAGGTTGCCT-3' }\end{array}$ & 60 & 341 \\
\hline Oct- $4^{\mathrm{c}}$ & AY490804 & $\begin{array}{l}5^{\prime} \text {-GTAATACGACTCACTATAGGGCCCAGGACATCAAAGCTCTTCAG-3' } \\
5^{\prime} \text {-GTAATACGACTCACTATAGGGGAACATGCTCTCCAGGTTGCCT-3' }\end{array}$ & & \\
\hline Histone $2 \mathrm{a}^{\mathrm{b}}$ & NM178409 & $\begin{array}{l}5^{\prime} \text {-CTCGTCACTTGCAACTTGCTATTC-3' } \\
5^{\prime} \text {-CCAGGCATCCTTTAGACAGTCTTC-3' }\end{array}$ & 60 & 148 \\
\hline
\end{tabular}

The primer used for ${ }^{\mathrm{a}} \mathrm{DNA}$ template amplification, ${ }^{\mathrm{b}}$ real-time PCR and ${ }^{\mathrm{c}}$ coupled with T7 promoter (underlined) DNA template for in vitro transcription. 
The first round of PCR amplification was performed using Taq DNA polymerase (Sigma). At first, the sample was heated at $95^{\circ} \mathrm{C}$ for $5 \mathrm{~min}$ followed by 35 cycles of denaturing at $94{ }^{\circ} \mathrm{C}$ for $30 \mathrm{~s}$, annealing at temperatures as indicated in Table 1 for $30 \mathrm{~s}$ and extension at $72{ }^{\circ} \mathrm{C}$ for $1 \mathrm{~min}$. Following the last cycle, a 10-min elongation step at $72{ }^{\circ} \mathrm{C}$ was performed. The same PCR conditions have also been used for the second round of PCR amplification using a primer attached with T7 promoter (GTAATACGACTCACTATAGGG) to its $5^{\prime}$-end to generate two different templates for in vitro transcription to produce sense and antisense RNA strands (Table 1). These C-mos and Oct-4 specific templates were purified using the QIAquick PCR Purification Kit (Qiagen).

\section{Synthesis of dsRNA}

The dsDNA templates coupled with T7 promoter were in vitro transcribed using RiboMAX Large Scale RNA Production T7 Systems (Promega) by which sense and antisense strands were transcribed from DNA template in separate reactions (Wianny \& Zernicka-Goetz 2000). After in vitro transcription, the DNA template was removed by digestion with RNase-free DNase at $37^{\circ} \mathrm{C}$ for $15 \mathrm{~min}$. Subsequently, the annealing of sense and antisense RNA strands was performed by incubating the reaction at $37{ }^{\circ} \mathrm{C}$ for $4 \mathrm{~h}$ after heating to $68{ }^{\circ} \mathrm{C}$ for $10 \mathrm{~min}$ to produce the dsRNA (Wianny \& Zernicka-Goetz 2000). Following a phenol/chloroform extraction, the RNA was precipitated with 0.1 volume of $3 \mathrm{M}$ sodium acetate $(\mathrm{pH}$ 5.2 ) and 2.5 volume of $100 \%$ ethanol. After centrifugation at $15000 \mathrm{rpm}$ at $4{ }^{\circ} \mathrm{C}$ for $30 \mathrm{~min}$, the resulting pellets were washed with $70 \%$ ethanol. Finally, the dsRNA pellets were resuspended in $10 \mu$ diethylpyrocarbonate (DEPC)-treated water. The RNA concentration was measured by ultraviolet light absorbance using Ultraspec 2100 pro spectrophotometer (Amersham Biosciences). Both C-mos and Oct-4 dsRNA were diluted in DEPC-treated water to obtain a final concentration of $10 \mu \mathrm{g} / \mu \mathrm{l}$ and stored at $-80^{\circ} \mathrm{C}$ until used during microinjection of oocytes and zygotes. Two microlitres of the dsRNA and DNA template were resolved by electrophoresis on a $2 \%$ agarose gel to evaluate the size and purity of the dsRNA (Fig. 1).

\section{Oocyte recovery and in vitro maturation}

Bovine ovaries were obtained from a local slaughterhouse and transported to the laboratory within 2-4 h after slaughter in a thermoflask containing a $0.9 \%$ saline solution supplemented with streptocombin. The cumulus oocyte complexes (COCs) were aspirated from follicles (2-8 $\mathrm{mm}$ in diameter) with an 18-gauge needle and COCs with multiple layers of cumulus cells were selected for in vitro maturation. The selected oocytes were washed in maturation medium (modified Parker medium, MPM)

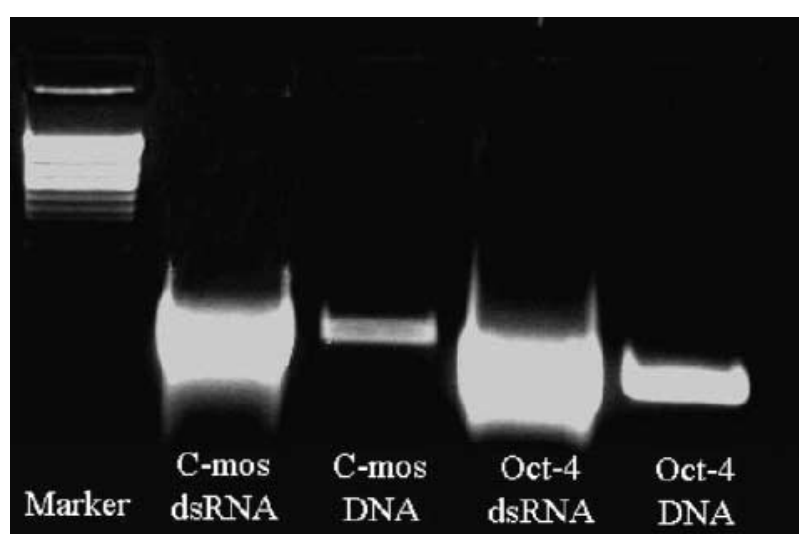

Figure 1 Two per cent agarose gel stained with ethidium bromide showing the bands of C-mos (435 bp) and Oct-4 (341 bp) dsRNA compared with DNA template used for in vitro transcription.

supplemented with $15 \%$ oestrus cow serum (OCS), $0.5 \mathrm{mM}$ L-glutamine, $0.2 \mathrm{mM}$ pyruvate, $50 \mu \mathrm{g} / \mathrm{ml}$ gentamycin sulphate and $10 \mu \mathrm{l} / \mathrm{ml} \mathrm{FSH} \mathrm{(Folltropin,} \mathrm{Vetre-}$ pharm, Canada) before being set into culture. The COCs were cultured in groups of 50 in $400 \mu \mathrm{l}$ of maturation medium under mineral oil in four-well dishes (Nunc, Roskilde, Denmark). Maturation was performed for $24 \mathrm{~h}$ at $39{ }^{\circ} \mathrm{C}$ under a humidified atmosphere of $5 \% \mathrm{CO}_{2}$ in air.

\section{In vitro fertilization of oocytes}

After maturation, COCs were transferred into four-well dishes containing $400 \mu \mathrm{l}$ of fertilization medium (FertTALP) supplemented with $2 \mu \mathrm{g} / \mathrm{ml}$ of heparin (Sigma), $0.2 \mathrm{mM}$ pyruvate (Sigma) and $25 \mu \mathrm{l} / \mathrm{ml}$ penicillinamine, hypotaurine, adrenaline (epinephrine) (PHE). A swim-up procedure has been applied to obtain motile sperm cells from frozen-thawed semen (Parrish et al. 1988). Briefly, frozen-thawed sperm cells were incubated in a tube containing $1.5 \mathrm{ml}$ of sperm-TALP supplemented with $6 \mathrm{mg} / \mathrm{ml} \mathrm{BSA}$ and $10 \mathrm{mM}$ pyruvate for $50 \mathrm{~min}$ at $39^{\circ} \mathrm{C}$ in a humidified incubator with $5 \% \mathrm{CO}_{2}$. After this time, the supernatant was recovered and centrifuged at $250 \mathrm{~g}$ for $10 \mathrm{~min}$ at room temperature to recover motile sperm cells as a pellet. In vitro fertilization was performed using a final concentration of $2 \times 10^{6}$ sperm cells $/ \mathrm{ml}$ in $400 \mu \mathrm{l}$ fertilization drop containing a group of 50 COCs. Fertilization was initiated during co-incubation of spermatozoa and the matured oocytes for $20 \mathrm{~h}$ in the same incubator under the same temperature and atmospheric $\mathrm{CO}_{2}$ content as used for maturation.

\section{In vitro embryo culture}

Following insemination, presumptive zygotes were stripped off from residual cumulus cells and attached spermatozoa by vortexing for $90 \mathrm{~s}$ in Charles Rosenkrans 1 (CR1) culture medium. After treatment, zygotes were 
washed once in fresh culture medium and cultured in groups of up to 50 zygotes in four-well dishes each containing $400 \mu \mathrm{l} \mathrm{CR} 1$ medium (Tesfaye et al. 2004) until day 8 after insemination. The CR1 medium is supplemented with $10 \%$ OCS, $20 \mu \mathrm{l} / \mathrm{ml}$ Eagle's basal medium (BME) (amino acids) and $10 \mu \mathrm{l} / \mathrm{ml}$ Minimum essential medium (MEM) (non-essential amino acids) (Gibco BRL). Cleavage rate was assessed $48 \mathrm{~h}$ after insemination, while morula and blastocyst rate were determined at days 5 and 6-8 after insemination respectively. In vitro culture was also performed in a humidified atmosphere with $5 \% \mathrm{CO}_{2}$ at $39^{\circ} \mathrm{C}$.

\section{Microinjection of dsRNA}

In this study, two experiments were conducted to attain the objectives. In experiment 1 , the effect of suppression of C-mos during oocyte maturation was assessed by microinjection of C-mos dsRNA at the immature oocyte stage. Oocytes used in this study were aspirated from cattle ovaries collected from a nearby slaughterhouse. Only good quality oocytes were selected for the experiment based on their morphological characteristics, mainly the intactness of the cumulus cells. Once the oocytes were selected, the cumulus cells were partially removed (Fig. 2A) by vortexing to avoid technical difficulties during microinjection of the dsRNA or water in the cytoplasm of the oocytes. Until used for microinjection, oocytes were held in tissue culture medium (TCM)-199 supplemented with $0.1 \%$ BSA (Sigma), $0.2 \mathrm{mM}$ pyruvate and $50 \mu \mathrm{g} / \mathrm{ml}$ gentamycin sulphate (Sigma) in a humidified atmosphere with $5 \%$ $\mathrm{CO}_{2}$ at $39{ }^{\circ} \mathrm{C}$ for $1-2 \mathrm{~h}$. Prior to microinjection, immature oocytes were incubated for $20 \mathrm{~min}$ in TCM-199 supplemented with cytochalasin $\mathrm{B}$ at a final concentration of $8 \mu \mathrm{g} / \mathrm{ml}$ in order to reduce mechanical damage during injection (Paradis et al. 2005). Subsequently, in three experimental replicates, a total of 935 immature oocytes were divided into three groups: C-mos dsRNA-injected (group 1, $n=327$ ), water-injected group (group 2, $n=$ 303 ) and uninjected controls (group 3, $n=305$ ).

In experiment 2, the effect of suppression of embryonic Oct-4 gene using sequence-specific dsRNA on the mRNA expression and protein synthesis and in vitro development of embryos was also investigated after microinjection at the zygote stage. Zygotes were collected at 22-24 h post-fertilization from the fertilization medium and washed twice in CR1 medium before being used in the experiment. For this, a total of 1115 zygote-stage bovine embryos were produced as indicated above and categorized into three groups: those injected with Oct-4 dsRNA (group 1, $n=365$ ), those injected with water (group 2, $n=375$ ) and uninjected controls (group 3, $n=541$ ).

In both experiments, microinjection was performed on an inverted microscope (Leica DM-IRB) at $200 \times$
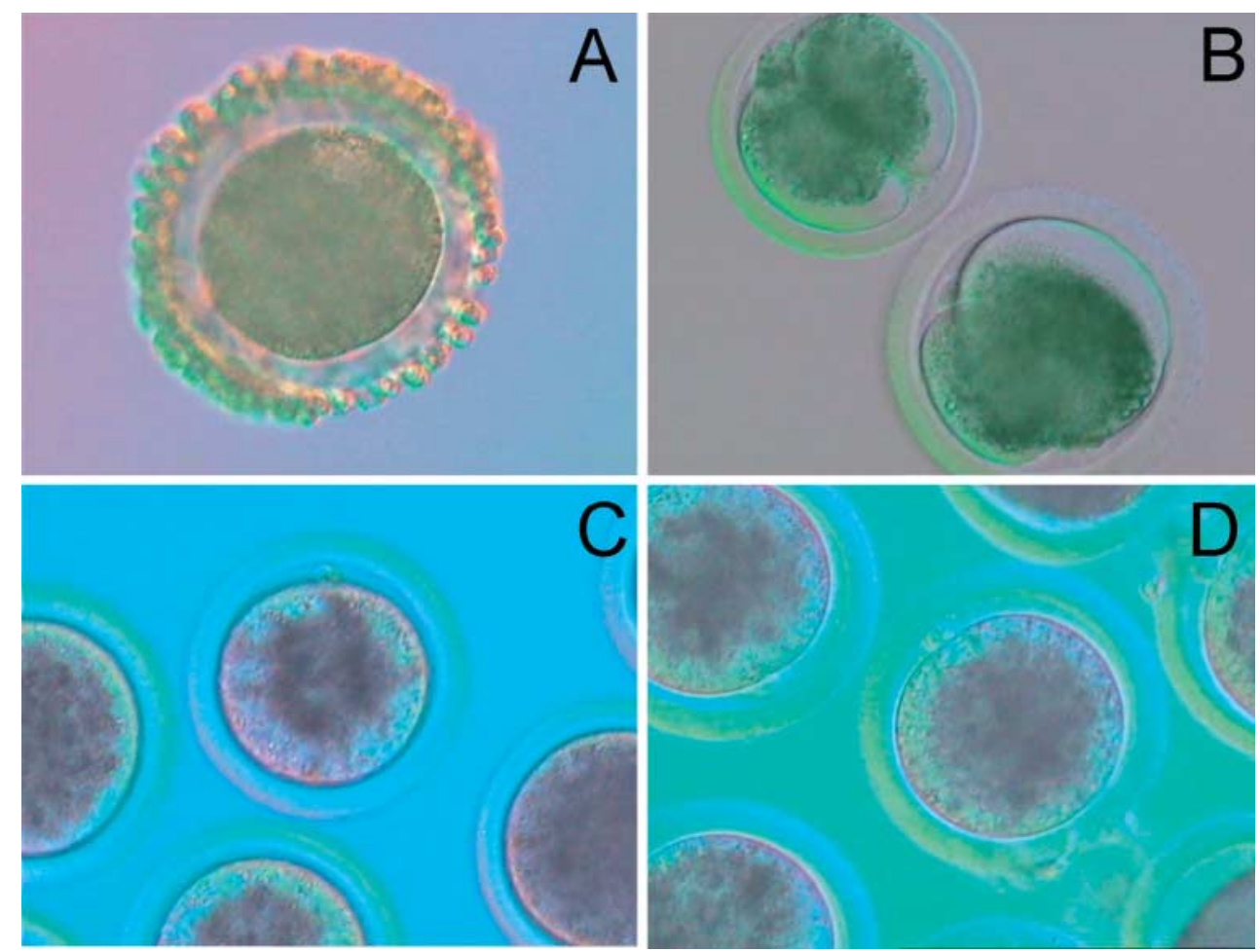

Figure 2 Representative images of oocytes, whose cumulus cells are partially removed, before any treatment (A); some parthenogenetically developed oocytes after injection with C-mos dsRNA (B); those oocytes injected with water (C) and uninjected controls (D). 
magnification. During microinjection a group of 50-60 immature oocytes or zygotes were placed in a $10 \mu \mathrm{l}$ droplet of Hepes-buffered TCM 199 (H-TCM) under mineral oil and the dsRNA or water was placed in a $1 \mu \mathrm{l}$ droplet near to the droplet containing the oocytes or zygotes. However, H-TCM medium was supplemented with cytochalasin B during the injection of immature oocytes to improve the survival rate of the oocytes after microinjection (Paradis et al. 2005). Injection was performed by aspiration of the dsRNA $(10 \mu \mathrm{g} / \mu \mathrm{l})$ or water into the injection capillary (Cook, Ireland, K-MPIP-3335-5). The injection volume of $\sim 7 \mathrm{pl}$ was estimated from the displacement of the meniscus of mineral oil in the capillary, which is $1 \mu \mathrm{m}$ in diameter. The different treatment groups were injected one after the other, every time preparing a new dish with fresh medium. After microinjection, all groups of immature oocytes or zygotes were washed twice in CR1 aa medium and set back into culture. Their survival rate was assessed 3-4 $\mathrm{h}$ after microinjection.

\section{Oocytes and embryos collection}

In order to assess the effect of sequence-specific dsRNA in oocytes and embryo on mRNA transcript abundance and protein expression, oocytes and embryos were collected at specific times after treatment for mRNA and protein analysis. In experiment 1, immature oocytes were cultured after microinjection with C-mos dsRNA or water until $48 \mathrm{hpi}$. While oocytes were cultured for $48 \mathrm{~h}$ after treatment to allow any parthenogenetic development, those used for transcriptional and protein expression analysis were collected at $24 \mathrm{~h}$ after microinjection and subsequent maturation. In experiment 2, zygotes injected with Oct-4 dsRNA or water and uninjected controls were cultured in vitro until day 8 blastocyst stage to assess development. The resulting blastocysts from each treatment group were used for both transcription and protein analysis.

Prior to freezing for mRNA or protein expression analysis, all oocytes/embryos were washed twice with PBS (Sigma) and treated with acidic Tyrode $\mathrm{pH} 2.5-3$ (Sigma) to dissolve the zona pellucida. The zona-free oocytes and embryos were further washed twice in drops of PBS and frozen in cryo-tubes containing minimal amounts of lysis buffer (0.8\% Igepal (Sigma), $40 \mathrm{U} / \mu \mathrm{l}$ RNasin (Promega), $5 \mathrm{mM}$ dithiothreitol (DTT) (Promega)). Samples for Western blot analysis were additionally treated with protease inhibitor (Sigma). Until used for RNA isolation or Western blotting, all frozen embryos were stored at $-80{ }^{\circ} \mathrm{C}$.

\section{RNA isolation and reverse transcription}

A total of three pools each containing 20 matured oocytes or ten blastocyst stage embryos were used for
mRNA isolation using oligo $(\mathrm{dT})_{26}$ attached magnetic beads (Dynal, Oslo, Norway) following the manufacturer's instruction. Briefly, oocytes or embryos in lysis buffer were mixed with $40 \mu \mathrm{l}$ binding buffer $(20 \mathrm{mM}$ Tris- $\mathrm{HCl}$ with $\mathrm{pH} 7.5,1 \mathrm{M} \mathrm{LiCl}, 2 \mathrm{mM}$ EDTA with $\mathrm{pH}$ 8.0) and incubated at $70^{\circ} \mathrm{C}$ for 5 min to obtain complete lysis of the embryo and release of RNA. Ten microlitres of oligo $(\mathrm{dT})_{25}$ magnetic bead suspension was added to the samples and incubated at room temperature for $30 \mathrm{~min}$. The hybridised mRNA and oligo (dT) magnetic beads were washed three times with washing buffer $(10 \mathrm{mM}$ Tris- $\mathrm{HCl}$ with $\mathrm{pH} 7.5,0.15 \mathrm{mM} \mathrm{LiCl}, 1 \mathrm{mM}$ EDTA with $\mathrm{pH}$ 8.0). Finally, mRNA samples were eluted in $12 \mu \mathrm{l}$ DEPC-treated water and reverse transcribed in $20 \mu \mathrm{l}$ reaction volume containing $2.5 \mu \mathrm{M}$ oligo (dT) $12 \mathrm{~N}$ (where $\mathrm{N}=\mathrm{G}, \mathrm{A}$ or $\mathrm{C}$ ) primer, $4 \mu \mathrm{l}$ of $5 \times$ first stand buffer $(375 \mathrm{mM} \mathrm{KCl}, 15 \mathrm{mM} \mathrm{MgCl} 2,250 \mathrm{mM}$ Tris- $\mathrm{HCl}$ $\mathrm{pH} 8.3), 2.5 \mathrm{mM}$ of each dNTP, $10 \mathrm{U}$ RNase inhibitor (Promega) and $100 \mathrm{U}$ of SuperScript II reverse transcriptase (Invitrogen). In terms of the order of adding reaction components, mRNA and oligo (dT) primer were mixed first, heated to $70^{\circ} \mathrm{C}$ for $3 \mathrm{~min}$, and placed on ice until the addition of the remaining reaction components. The reaction was incubated at $42{ }^{\circ} \mathrm{C}$ for $90 \mathrm{~min}$ and terminated by heat inactivation at $70{ }^{\circ} \mathrm{C}$ for $15 \mathrm{~min}$.

\section{Real-time quantitative PCR}

Quantification of C-mos, Oct-4 and Histone 2a (H2a) as endogenous control mRNA in the oocytes/embryos of each treatment group was assessed by real-time quantitative PCR. Furthermore, independent maternal transcript growth differentiation factor 9 (Gdf-9) has been quantified in the three treatment groups of experiment 1 to assess the specificity of mRNA suppression by the C-mos dsRNA. Similarly, the E-cadherin transcript has been quantified in the three treatment groups of experiment 2 to investigate the specificity of mRNA degradation by Oct-4 dsRNA. Moreover, the fibroblast growth factor (Fgf-4), which is reported to be coexpressed with Oct-4 gene (Nichols et al. 1998), has been quantified in the treatment groups of experiment 2 . The ABI Prism 7000 apparatus (Applied Biosystems) was used to perform the quantitative analysis using SYBR Green JumpStart Tag ReadyMix (Sigma) incorporation for dsDNA-specific fluorescent detection dye. Quantitative analyses of all studied transcripts were performed in comparison with $\mathrm{H} 2 \mathrm{a}$ as an endogenous control (Robert et al. 2002) and were run in separate wells. The primer sequences were designed for PCR amplification according to the bovine cDNA sequences (Table 1) using Primer Express Software v2.0 (Applied Biosystems). Standard curves were generated for both target and endogenous control genes using serial dilution of plasmid DNA $\left(10^{1}-10^{8}\right.$ molecules). The PCRs were performed in $20 \mu \mathrm{l}$ reaction volume containing $10 \mu$ I SYBR Green universal master mix (Sigma), optimal levels of forward and 
reverse primers and $2 \mu \mathrm{l}$ of embryonic cDNA. During each PCR reaction, samples from the same cDNA source were run in duplicate to control the reproducibility of the results. A universal thermal cycling parameter (initial denaturation step at $95{ }^{\circ} \mathrm{C}$ for $10 \mathrm{~min}, 45$ cycles of denaturation at $95^{\circ} \mathrm{C}$ for $15 \mathrm{~s}$ and $60^{\circ} \mathrm{C}$ for $60 \mathrm{~s}$ ) were used to quantify each gene of interest. After the end of the last cycle, a dissociation curve was generated by starting the fluorescence acquisition at $60{ }^{\circ} \mathrm{C}$ and taking measurements every $7 \mathrm{~s}$ until the temperature reached $95{ }^{\circ} \mathrm{C}$. Final quantitative analysis was done using the relative standard curve method as used in Tesfaye et al. (2004) and results are reported as the relative expression level compared to the calibrator cDNA after normalisation of the transcript amount to the endogenous control.

\section{Western blot analysis}

Groups of 120 matured oocytes and 50 embryos at day 7 blastocyst stage were used from each treatment group, which include C-mos or Oct-4 dsRNA-injected, waterinjected and uninjected control. In order to assess the amount of protein available before treatment in immature oocytes, equal amount of immature oocytes were also used for protein analysis prior to treatment. The proteins were extracted from the oocytes or embryos in loading buffer $(26 \%$ of Tris $1 \mathrm{M} \mathrm{pH} 6.8,12 \%$ SDS, $20 \%$ 2-mercaptoethanol and $40 \%$ glycerol). Following boiling for $5 \mathrm{~min}$, proteins were separated on a $14 \%$ SDS-PAGE gel. Proteins were then transferred onto nitrocellulose transfer membrane, pore size $0.45 \mu \mathrm{m}$ (Protran, Schleicher \& Schuell BioScience, Dassel, Germany) using Trans-Blot SD; semi-dry transfer cell (BioRad). The membrane was stained with Ponceau $\mathrm{S}$ to evaluate the transfer quality and blocked for $1 \mathrm{~h}$ in Trisbuffered saline $(20 \mathrm{mM}$ Tris $\mathrm{pH} 7.5,150 \mathrm{mM} \mathrm{NaCl})$ containing $0.05 \%$ Tween-20 (TBS-T) and $1 \%$ polyvinylpyrrolidone (PVP) (Sigma). The membrane was then incubated at $4{ }^{\circ} \mathrm{C}$ overnight with the anti-rabbit C-mos primary antibody (Stressgen, Victoria, Canada) or Oct3/4 (N-19) goat polyclonal primary antibody (Santa Cruz Biotechnology, Heidelberg, Germany). The primary antibody was diluted 1:500 in TBS-T containing $0.1 \%$ PVP prior to use. After incubation with the primary antibody, the membrane was washed six times for $10 \mathrm{~min}$ in TBS-T and the hybridization with the secondary antibody was performed at room temperature for $1 \mathrm{~h}$. The horseradish-peroxidase (HRP) conjugated donkey anti-rabbit secondary antibody (Amersham Bioscience) and donkey anti-goat IgG-HRP secondary antibody (Santa Cruz Biotechnology) were used as secondary antibodies for C-mos and Oct-4 protein detection, respectively. Both secondary antibodies were diluted 1:50 000 in TBS-T containing 0.1\% PVP. The membrane was finally washed six times for $10 \mathrm{~min}$ in TBS-T. The peroxidase activity was detected using the
ECL Plus Western Blotting Detection System (Amersham Bioscience) following the manufacturer's instructions and visualized using Kodak BioMax XAR film (Kodak).

\section{Differential cell staining of blastocysts}

Differential staining of inner cell mass (ICM) and trophectoderm (TE) cells of bovine day 8 blastocysts from the three treatment groups was performed by incubating in freshly prepared permeabilising solution $1 \%$ Triton X-100 and $1 \mu \mathrm{g} / \mu \mathrm{l}$ propidium iodide in PBS containing $1 \mathrm{mg} / \mathrm{ml}$ BSA for $50 \mathrm{~s}$. After washing twice in PBS-BSA medium, embryos were transferred into ethanol containing $0.03 \mu \mathrm{g} / \mu \mathrm{l}$ bisbenzimide (Hoechst 33258; Hoechst, Sigma), incubated for 4 min on an ice block and washed twice in PBS-BSA medium. Embryos were immediately mounted on glass slides and examined under fluorescence microscope to determine the number of ICM and TE cells.

\section{Statistical analysis}

The mRNA expression analysis for studied genes in all treatment groups was analysed based on the relative standard curve method. The relative expression data were analysed using the statistical analysis system (SAS) version 8.0 (SAS Institute Inc., Cary, NC, USA) software package. Differences in mean values between two or more experimental groups or developmental stages were tested using ANOVA followed by a multiple pair wise comparison using $t$-test. Differences of $P<0.05$ were considered to be significant.

\section{Results \\ Experiment 1: effect of C-mos dsRNA on oocyte maturation, mRNA and protein expression}

\section{Effect of C-mos dsRNA on in vitro maturation of oocytes}

The survival rate of the oocytes due to physical injury during microinjection was determined $3-4 \mathrm{~h}$ after microinjection. As indicated in Table 2, no significant differences were observed in survival rate of immature oocytes injected with C-mos dsRNA and water $(P>0.05)$. Compared to uninjected controls about $10 \%$ of injected oocytes did not survive the microinjection procedure. Sixty percent of oocytes injected with C-mos dsRNA showed extrusion of the first polar body after $24 \mathrm{~h}$ maturation, while only 50 and $44 \%$ of water injected and uninjected controls, respectively, showed first polar body extrusion as shown in Table 2. Moreover, about $2.5 \%$ of the oocytes injected with C-mos dsRNA developed parthenogenetically to the two-cell stage, while no parthenogenetic development was observed in the water-injected group and uninjected controls (Fig. 2). 
Table 2 The phenotypes of embryo development following treatment with C-mos dsRNA and water compared to the uninjected controls.

\begin{tabular}{lcccc}
\hline Treatment group & No. of oocytes & $\begin{array}{c}\text { Survival rate at 3-4 h } \\
\text { after treatment }(\%)\end{array}$ & $\begin{array}{c}\text { Polar body extrusion at } \\
\mathbf{4 8} \mathbf{h} \text { after treatment }(\%)\end{array}$ & $\begin{array}{c}\text { Pathenogenetic developed oocytes } \\
\text { at 48 h post-injection }(\%)\end{array}$ \\
\hline C-mos dsRNA-injected & 327 & $90.42 \pm 4.11$ & $59.12 \pm 9.30^{\mathrm{a}}$ & $2.42 \pm 0.39^{\mathrm{a}}$ \\
Water-injected & 303 & $88.21 \pm 5.31$ & $49.50 \pm 14.88^{\mathrm{a}, \mathrm{b}}$ & $0^{\mathrm{b}}$ \\
Uninjected control & 305 & $100.00 \pm 0.00$ & $44.05 \pm 17.20^{\mathrm{b}}$ & $0^{\mathrm{b}}$ \\
\hline
\end{tabular}

Superscripts with different letters $(a, b)$ indicate significant differences within the same column $(P \leq 0.05)$.

Temporal expression pattern of maternal transcripts (C-mos and Gdf-9) and the effect of C-mos dsRNA on targeted mRNA

In order to get insight into the normal temporal expression pattern of the studied maternal transcripts (C-mos and Gdf-9), a real-time PCR analysis was conducted throughout the preimplantation developmental stages of in vitro produced bovine embryos (Fig. 3). The C-mos and Gdf-9 were detected at higher level between immature oocyte and four-cell developmental stage and down-regulated or not detected in the later developmental stages.

In order to assess the effect of C-mos dsRNA on the target mRNA, the relative expression level of this transcript was investigated between the treatment groups. Moreover, the selective suppression efficiency of C-mos dsRNA was assessed analysing the expression level of other maternal transcript (Gdf-9) between the same treatment groups. As shown in Fig. 4, the relative expression level of C-mos transcript at the matured oocyte stage was found to be reduced by $70 \%$ compared to water injected and uninjected control group $(P<0.01)$. However, no significant differences were observed in the relative abundance of this transcript between the water-injected group and uninjected controls. No differences were observed in the relative abundance of Gdf-9 transcript between the three treatment groups. This shows that neither the injection of water nor C-mos dsRNA affected the expression of Gdf-9 mRNA in the treated oocytes.

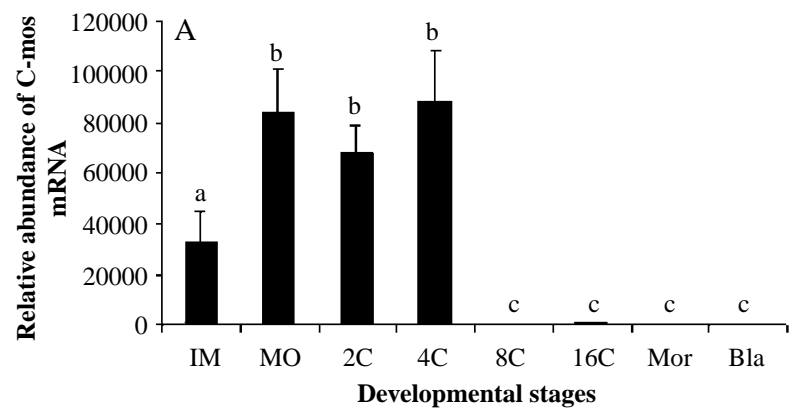

\section{Effect of C-mos dsRNA on protein expression}

To determine the effect of C-mos dsRNA on C-mos protein expression, Western blot analysis was performed using proteins extracted from matured oocytes of the three treatment groups. Moreover, protein extracted from oocytes at germinal vesicle (GV) stage and bovine muscle were used as positive control. As shown in Fig. 5, there is a decrease in the intensity of C-mos protein band $(39 \mathrm{kDa})$, while strong reactive bands were detected in the water-injected and uninjected control groups.

\section{Experiment 2: effect of Oct-4 dsRNA on embryo development, mRNA and protein expression}

\section{Effect of Oct-4 dsRNA on in vitro development of bovine embryos}

The survival rate of embryos after microinjection has been determined and no significant differences were observed between zygotes injected with dsRNA or water as shown in Table 3. Compared to uninjected controls about $15 \%$ of embryos did not survive the microinjection procedure. The first cleavage rate after microinjection was 70, 80 and $81 \%$ for embryos injected with Oct- 4 dsRNA and water and for uninjected controls respectively. However, these differences were not significant. Similarly, the day 5 morula rate was not significantly different between the three embryo groups, i.e. $38 \%$ in the Oct- 4 dsRNA-injected, $40 \%$ in the water-injected

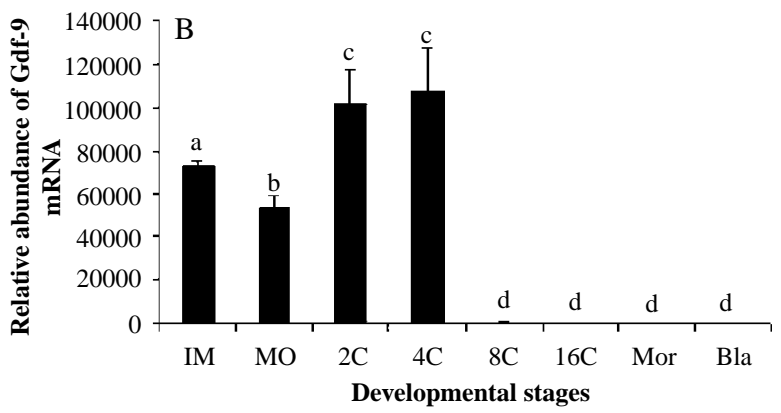

Figure 3 Relative abundance of C-mos (A) and Gdf-9 (B) mRNA in in vitro produced bovine preimplantation stage embryos: immature oocyte (IM); mature oocyte (MO); 2-cell (2C); 4-cell (4C); 8-cell (8C); 16-cell (16C); morula (Mor); blastocyst (Bla). The relative abundance of mRNA levels represents the normalized quantity of mRNA compared to the calibrator (blastocyst stage) which is set to 100. Individual bars show the treatment mean \pm s.D. Values with different superscripts $(\mathrm{a}, \mathrm{b}, \mathrm{c}, \mathrm{d})$ are significantly different $(P \leq 0.05)$. 

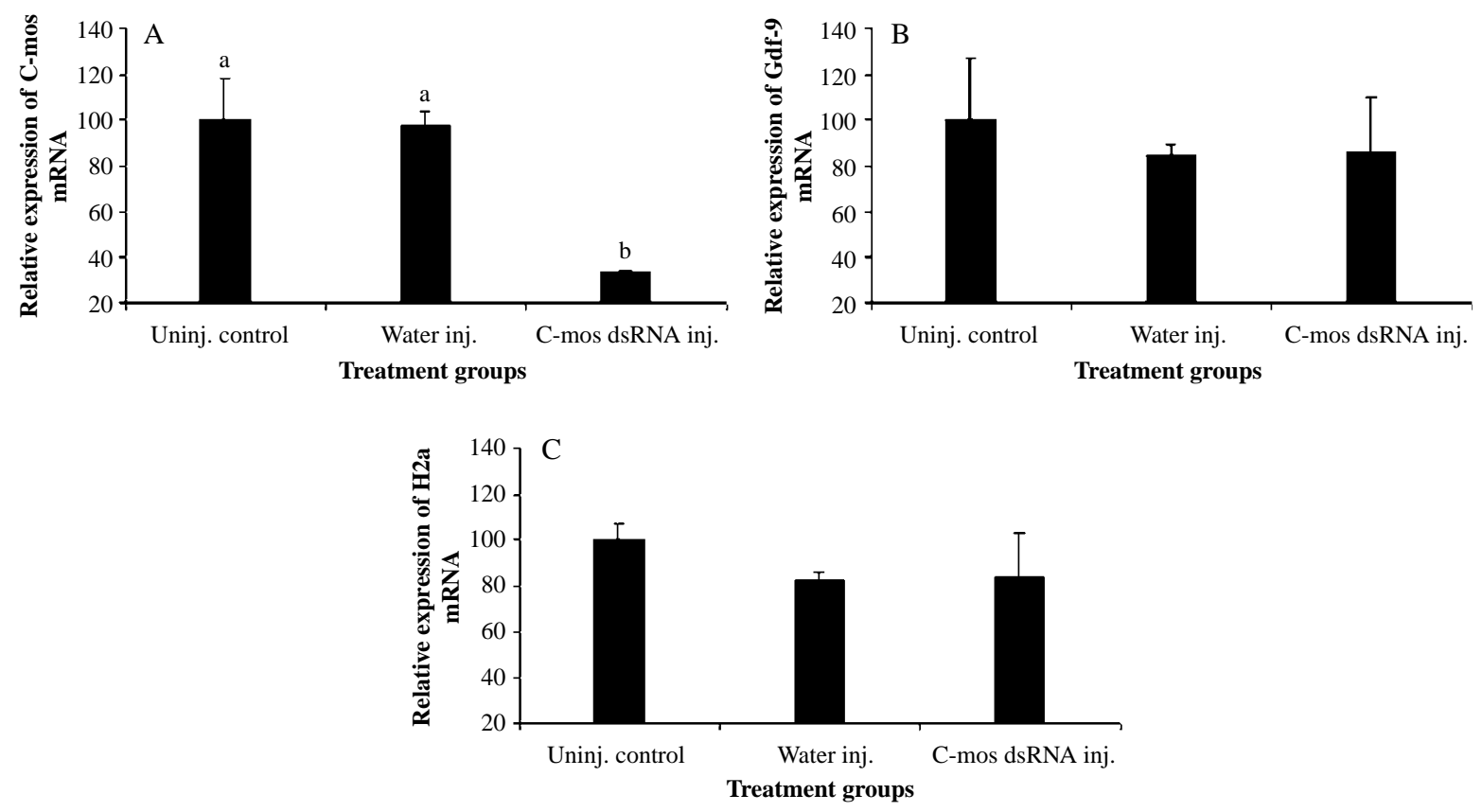

Figure 4 Relative abundance of C-mos (A), Gdf-9 (B) and H2a (C) transcripts in oocytes at $24 \mathrm{~h}$ post-injection of dsRNA or water and in uninjected controls. The relative abundance of mRNA levels represents the amount of mRNA compared to the calibrator (Uninj. control) which is set to 100; injected (inj). Individual bars show the mean \pm s.D. Values with different superscripts $(\mathrm{a}, \mathrm{b})$ are significantly different $(P \leq 0.05)$.

and $41 \%$ in the uninjected control group $(P>0.05)$. There is a considerable variation in the number of blastocysts that appeared from each treatment group at each day of development between days 6 and 8 (Table 3). Even though the overall blastocyst rate was lower in Oct-4 dsRNA-injected groups $(35.8 \pm 1.5 \%)$ compared to the water-injected group $(39.7 \pm 2.6 \%)$ and uninjected controls $(41.6 \pm 4.15 \%)$, these differences are not significant $(P>0.05)$.

\section{Temporal expression profile of Oct-4 and Fgf-4 in bovine preimplantation stage embryos}

The Oct-4 transcript was quantified throughout the preimplantation developmental stages of in vitro produced bovine embryos. This transcript was found to be highly abundant at early developmental stages (between immature oocytes and four-cell stages) and further down-regulated between eight-cell and morula stages. Relatively higher transcript abundance was also detected at the blastocyst stage. The Fgf-4 transcript was highly abundant only at morula and blastocyst stages but could not be detected in earlier developmental stages: from immature oocytes up to 16-cell stages (Fig. 6).

Effect of Oct-4 dsRNA on targeted mRNA and coexpressed genes

The results of mRNA transcript analysis in all treatment groups showed that Oct-4 mRNA was down-regulated by $72 \%$ in the Oct- 4 dsRNA-injected group compared to the water-injected and uninjected control groups $(P<0.01)$. In order to investigate the specificity of the Oct-4 dsRNA, E-cadherin gene was quantified in all treatment groups and no differences were subsequently found in the relative abundance of the E-cadherin subtranscript in all treatment groups. Moreover, the relative expression of Fgf-4 gene, which is known to be co-expressed with Oct-4, was found to be significantly down-regulated by $70 \%$ in the Oct-4 dsRNA-injected group compared to the other two groups as shown in Fig. $7(P<0.01)$.

\section{Effect of Oct-4 dsRNA on protein expression}

To determine the effect of Oct-4 dsRNA on Oct-4 protein expression, Western blot analysis was performed using

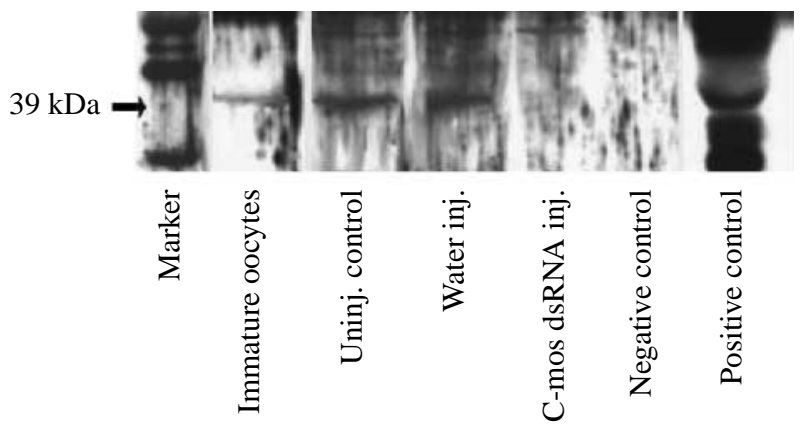

Figure 5 Western blot analysis for the presence of C-mos protein $(39 \mathrm{kDa})$ in bovine oocytes following C-mos dsRNA and water injection in immature oocytes before any treatment and in uninjected controls. Uninjected (Uninj.); Injected (inj.). 
Table 3 Embryo survival and development assessment data in the three embryo groups following treatment.

\begin{tabular}{|c|c|c|c|c|c|c|c|c|c|}
\hline Treatment group & $\begin{array}{l}\text { No. of } \\
\text { embryos }\end{array}$ & $\begin{array}{l}\text { Survival } \\
\text { rate }(\%)\end{array}$ & $\begin{array}{l}\text { Cleavage } \\
\text { rate }(\%)\end{array}$ & $\begin{array}{l}\text { Morula } \\
\text { rate }(\%)\end{array}$ & $\begin{array}{c}\text { Day } 6 \\
\text { blastocyst } \\
(\%)\end{array}$ & $\begin{array}{c}\text { Day } 7 \\
\text { blastocyst } \\
(\%)\end{array}$ & $\begin{array}{c}\text { Day } 8 \\
\text { blastocyst } \\
(\%)\end{array}$ & $\begin{array}{c}\text { Total } \\
\text { blastocyst } \\
(\%)\end{array}$ & $\begin{array}{l}\text { Blas/ } \\
\text { Mor }\end{array}$ \\
\hline $\begin{array}{l}\text { Oct- } 4 \text { dsRNA- } \\
\text { injected }\end{array}$ & 365 & $81.50 \pm 16.67^{\mathrm{a}}$ & $69.67 \pm 20.73$ & $37.27 \pm 3.25$ & $7.74 \pm 5.46$ & $18.48 \pm 2.46^{\mathrm{a}}$ & $9.64 \pm 4.50^{\mathrm{a}}$ & $35.85 \pm 1.53$ & 0.96 \\
\hline Water-injected & 375 & $86.80 \pm 9.34^{\mathrm{a}}$ & $80.04 \pm 7.07$ & $40.17 \pm 9.48$ & $10.81 \pm 2.57$ & $20.20 \pm 6.32^{\mathrm{a}, \mathrm{b}}$ & $8.68 \pm 1.404^{\mathrm{a}}$ & $39.69 \pm 2.57$ & 0.99 \\
\hline $\begin{array}{l}\text { Uninjected } \\
\text { control }\end{array}$ & 541 & $98.86 \pm 2.56^{b}$ & $80.50 \pm 7.65$ & $41.95 \pm 4.51$ & $12.80 \pm 9.09$ & $26.45 \pm 3.95^{\mathrm{b}}$ & $2.32 \pm 0.89^{b}$ & $41.57 \pm 4.15$ & 0.99 \\
\hline
\end{tabular}

Superscripts with different letters $(a, b)$ indicate significant differences within the same column $(P \leq 0.05)$.

protein extracted from embryos at the blastocyst stage of the three treatment groups - those injected with Oct-4 dsRNA, those injected with water and those uninjected controls. Moreover, in vitro matured bovine oocytes before any treatment were used to assess Oct- 4 protein produced from the maternal genome. Protein extracted from bovine brain was used as positive control. As shown in Fig. 8, there is a decrease in the intensity of the Oct-4 protein reactive band $(42 \mathrm{kDa})$, while strong reactive bands were detected in the water-injected and uninjected control groups.

Effect of Oct-4 down regulation in the number of ICM and TE cells of blastocysts

Differential cell staining of a representative number of blastocysts from the three treatment groups showed that the number of ICM cells was significantly lower in Oct-4 dsRNA-injected embryos (27.4 \pm 7.3$)$ compared to the other two groups (Table 4). However, no differences were observed in the number of TE cells between the three treatment groups. Consequently, the ratio of ICM:TE cells was lower $(P<0.05)$ in Oct-4 dsRNA-injected groups than in the other two groups. The total cell number of blastocysts was consequently lower in the Oct-4 dsRNAinjected group $(122.5 \pm 16.5)$ compared to the waterinjected group $(134.3 \pm 6.8)$ and uninjected controls $(140.2 \pm 18.4)$.

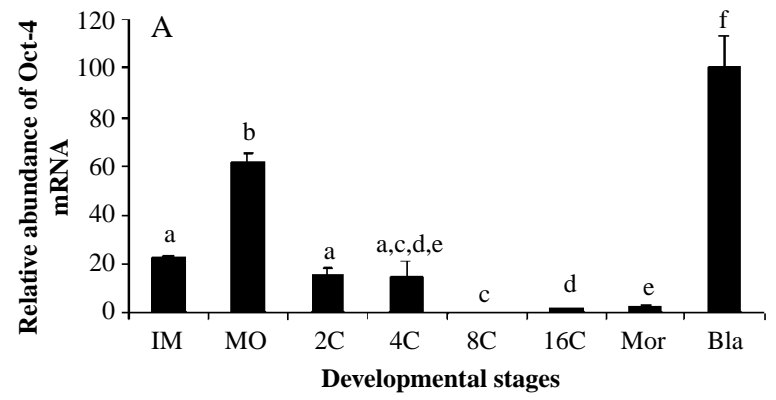

\section{Discussion}

Bovine preimplantation embryogenesis is supported by transcripts activated from both maternal and embryonic genome. Despite enormous advances in the identification and temporal expression profiling of bovine preimplantation genes, the specific function of the majority of transcripts is not yet known in bovine embryogenesis. Until recently, the function of a specific gene in bovine species has been predicted using knockout experiments conducted in mice (Larue et al. 1994, Riethmacher et al. 1995), which is an extremely long and laborious process in order to see any effects. To overcome this, the RNAi approach through introduction of sequence-specific dsRNA into the cells has been reported for various vertebrates and non-vertebrates as an effective tool to study gene function. Consequently, in the present study, we have demonstrated that the injection of sequence-specific dsRNA into the cytoplasm of bovine oocytes and zygotes induced suppression of maternal and embryonic transcript abundance, respectively, and resulted in subsequent decrease in protein synthesis and distinct phenotype.

The microinjection procedure used to introduce the dsRNA in the present study is known to be advantageous over other techniques like electroporation (Grabarek et al. 2002) and transfection technique (Siddall et al. 2002) in controlling the amount of dsRNA to be

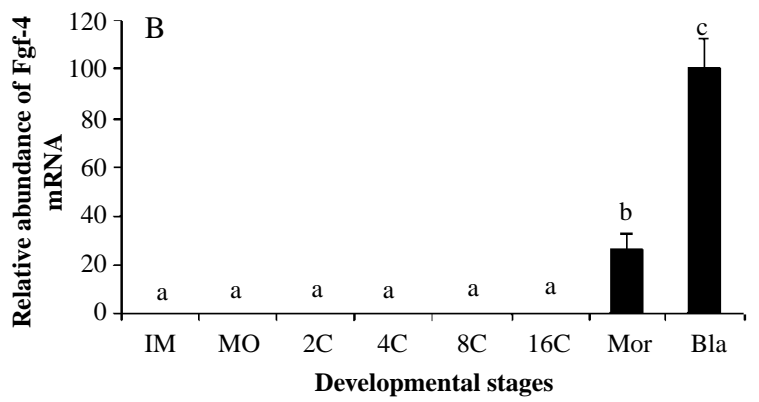

Figure 6 Relative abundance of Oct-4 and Fgf-4 mRNA in in vitro bovine preimplantation stage embryos: immature oocyte (IM); mature oocyte (MO); 2-cell (2C); 4-cell (4C); 8-cell (8C); 16-cell (16C); morula (Mor); blastocyst (Bla). The relative abundance of mRNA levels represents the amount of mRNA compared to the calibrator (blastocyst stage) which is set to 100. Individual bars show the treatment mean \pm s.D. Values with different superscripts (a, b, c, d, e) are significantly different $(P \leq 0.05)$. 

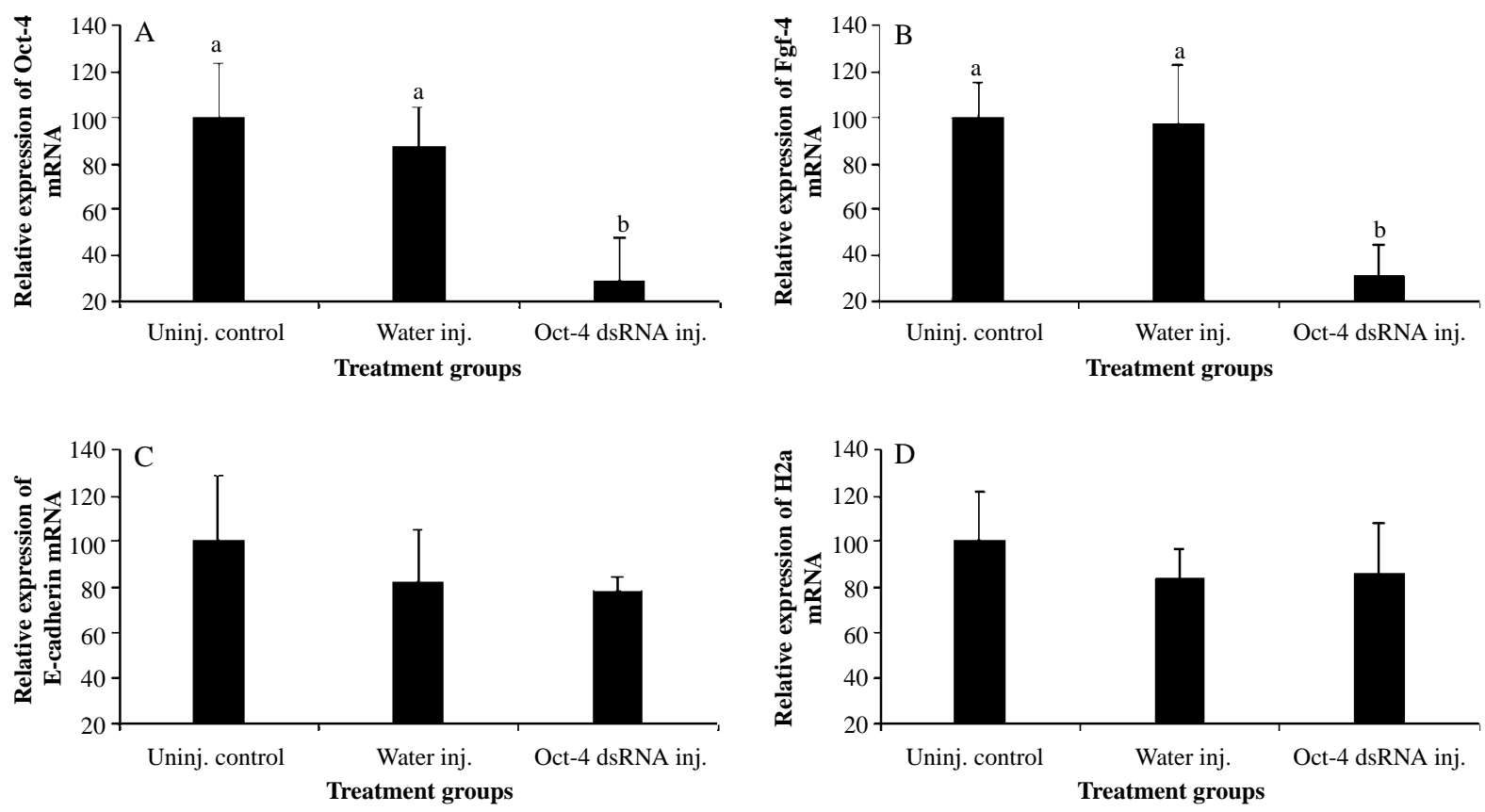

Figure 7 Relative abundance of Oct-4 (A), Fgf-4 (B), E-cadherin (C) and $\mathrm{H} 2 \mathrm{a}(\mathrm{D}) \mathrm{mRNA}$ at blastocyst stage in the three treatment groups. The relative abundance of mRNA levels represents the amount of mRNA compared to the calibrator (uninjected control) which is set as 100. Individual bars show the mean \pm s.D. Values with different superscripts $(\mathrm{a}, \mathrm{b})$ are significantly different $(P \leq 0.05)$. Uninjected (Uninj.); Injected (inj.).

introduced. In this method, physical injuries due to microinjection are inevitable. Consequently, in the present study, $10-15 \%$ of the oocytes and zygotes did not survive the microinjection procedure but this remains the same between the dsRNA- and waterinjected groups. Therefore, variation in developmental capacity due to the microinjection procedure has been ruled out.

Previous studies have shown that the mechanism of RNAi is limited at the post-transcriptional level by degrading the sequence-specific mRNA or blocking the activity of ribosomal RNA (rRNA) (Svoboda 2004), which leads to a loss of function in mice (Svoboda et al. 2000, Wianny \& Zernicka-Goetz 2000, Grabarek et al. 2002, Siddall et al. 2002). Our results also showed that the injection of dsRNA of oocyte- or zygote-specific transcripts induced sequence-specific mRNA degradation and prevented subsequent protein synthesis during development of preimplantation embryos. In the studies conducted in mouse, C-mos is known to play a role as an essential component of CSF, which is responsible for arresting the maturing oocytes at metaphase in the second meiotic division (Wianny \& Zernicka-Goetz 2000). In this study, the injection of C-mos dsRNA at the immature oocyte stage resulted in $70 \%$ reduction in the amount of C-mos mRNA after maturation compared to the waterinjected group and uninjected controls. This result is comparable with the results reported in mouse oocytes, where a suppression of $80 \%$ of C-mos mRNA was achieved by microinjection of C-mos dsRNA (Svoboda et al. 2000). Similar studies in mouse which targeted oocyte-specific maternal transcripts, namely Gdf-9 and Bmp-15, have shown the suppression of 89 and $78 \%$ in mRNA transcript abundance respectively (Gui \& Joyce 2005). Moreover, up to a level of $90 \%$ suppression in transcript abundance has been attained for Plat (Svoboda et al. 2000), ITPRT (Xu et al. 2003) and BNC (Ma et al. 2002) genes in mouse oocytes. A complete degradation of Cyclin B1 mRNA has been achieved in the work of Lazar et al. (2004)) in rat oocytes treated with Cyclin B1 dsRNA. A recent report from our group (Nganvongpanit et al. 2006), and also from others (Paradis et al. 2005), have shown suppression of transcripts between 80 and $90 \%$ in bovine oocytes and embryos. The efficiency of targeted suppression of transcripts in mammalian oocytes or

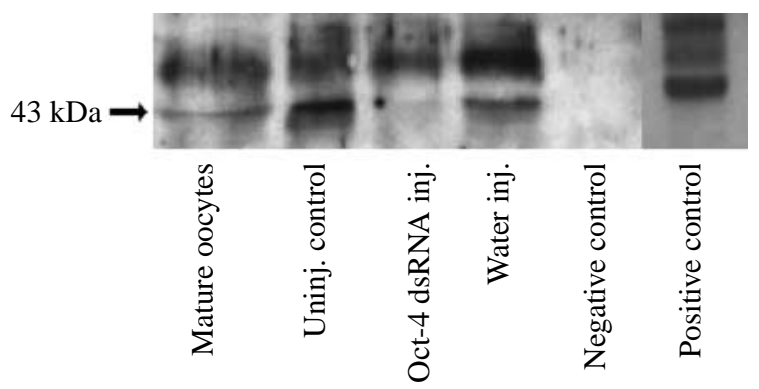

Figure 8 Western blot analysis results in the expression of Oct-4 protein $(43 \mathrm{kDa})$ in bovine embryos injected with Oct-4 dsRNA and water, uninjected controls and in matured oocytes prior to fertilization. Uninjected (Uninj.); Injected (inj.). 
Table 4 The number of ICM and TE cells (mean \pm s.D.) of day 8 blastocysts derived from the three treatment groups.

\begin{tabular}{llccrc}
\hline Treatment group & N & ICM & TE & Total & ICM:TE \\
\hline Oct-4 injected & 25 & $27.4 \pm 7.3^{\mathrm{a}}$ & $95.1 \pm 13.2^{\mathrm{a}}$ & $122.5 \pm 16.50^{\mathrm{a}}$ & $0.29 \pm 0.12^{\mathrm{a}}$ \\
Water injected & 27 & $40.9 \pm 8.2^{\mathrm{b}}$ & $94.4 \pm 8.9^{\mathrm{a}}$ & $134.3 \pm 6.8^{\mathrm{b}}$ & $0.42 \pm 0.18^{\mathrm{b}}$ \\
Uninjected controls & 26 & $41.0 \pm 4.8^{\mathrm{b}}$ & $99.2 \pm 18.6^{\mathrm{a}}$ & $140.2 \pm 18.4^{\mathrm{b}}$ & $0.43 \pm 0.17^{\mathrm{b}}$ \\
\hline
\end{tabular}

Columns with different superscript letters are significantly different $(P<0.05) ; N$ denotes number of blastocysts analysed, ICM denotes inner cell mass, TE denotes trophoectoderm.

embryos seems to determine the extent of change in developmental phenotype. This variation in the efficiency of suppression of mRNA and protein synthesis and the expected developmental phenotype using dsRNA may be associated with the concentration of dsRNA introduced. This has been evidenced by Wianny \& Zernicka-Goetz (2000), who have shown that $50 \%$ of the oocytes injected with $2 \mathrm{mg} / \mathrm{ml} \mathrm{C}$-mos dsRNA showed spontaneous activation while only $36 \%$ of the oocytes injected with $0.1 \mathrm{mg} / \mathrm{ml} \mathrm{C}$-mos dsRNA developed parthenogenetically to cleavage-stage embryos. Studies in C-mos ${ }^{-1-}$ knockout mouse have shown a reduced fertility because of the failure of mature eggs to arrest during meiosis (Colledge et al. 1994). The C-mos ${ }^{-1-}$ oocytes undergo GVBD and extrusion of both polar bodies, followed in some cases by progression into cleavage. In the present study, despite significant reduction in the transcript abundance and protein synthesis, the proportion of oocytes undergoing spontaneous activation after treatment with C-mos dsRNA was much lower compared to the studies in mouse (Wianny \& Zernicka-Goetz 2000). In the present study, $60 \%$ of C-mos dsRNA-injected oocytes showed extrusion of the first polar body, of which $2.5 \%$ showed spontaneous activation and development to two- to fourcell stage. However, while only $44-50 \%$ of the oocytes showed first polar body extrusion in the water-injected group and uninjected controls, no spontaneous activation and parthenogenetic development has been observed in these treatment groups. The reason for the lower percentage of spontaneous activation in C-mos dsRNAinjected groups compared to comparable studies in the mouse cannot be explained at this level of the study.

The C-mos proto-oncogene is reported to be expressed at high levels in testes and ovaries, specifically in male and female germ cells (Kiessling \& Cooper 1989). Quantitative expression analysis of C-mos and GDF-9 throughout the preimplantation stage showed a pattern similar to most maternal transcripts. High-level accumulation of C-mos transcript after $24 \mathrm{~h}$ in vitro maturation (IVM) in fully grown oocytes in this study is consistent with previous studies in various species including mouse (Goldman et al. 1987, Mutter \& Wolgemuth 1987) and human oocytes (Pal et al. 1994). Similarly, growth stage dependent analysis of Mos synthesis in bovine oocytes showed a higher level of Mos product in oocytes as they reached the MII stage (between 22 and $26 \mathrm{~h}$ of IVM) compared to low synthesis during the first $4 \mathrm{~h}$ of IVM and no synthesis in ageing MII-stage oocytes at 44-48 h IVM (Wu et al. 1997). This expression pattern from our study and also from others may suggest the requirement of Mos expression during MII arrest and its possible role in MPF activity to maintain MII arrest. A significant level of C-mos and GDF-9 expression after fertilisation in this study may show the potential role of these transcripts in early stages of embryonic development. Our results have demonstrated that the injection of C-mos dsRNA leads to the specific degradation of the C-mos mRNA without affecting the expression of other genes (Gdf-9 and $\mathrm{H} 2 \mathrm{a}$ ). These results are consistent with the results obtained in mouse, where the injection of dsRNA directed towards C-mos mRNA resulted in the suppression of the targeted mRNA without affecting the untargeted transcript (Svoboda et al. 2000). Previous reports in bovine oocytes also showed that the suppression of Cyclin B1 had no effect on the expression of housekeeping gene ( $\beta$-actin) or Cyclin B2, as a member of the Cyclin B family (Paradis et al. 2005). Moreover, our results have demonstrated that degradation of mRNA has resulted in a consequent reduction of protein synthesis as is evidenced by Western blot analysis.

Bovine embryogenesis in the early preimplantation stages is supported by mRNA and protein transcribed from maternal and embryonic genome. Until the major round of embryonic transcription during the 8- to 16-cell stage in bovine embryos, development is largely dependent on the transcripts and protein formed by the oocyte (Memili \& First 2000). Oct-4 is the earliest expressed transcription factor that is known to be crucial in murine preimplantation development (Okamoto et al. 1990, Rosner et al. 1990, Schöler et al. 1990). The mRNA and protein of Oct- 4 have been found in murine oocytes and in the nuclei of subsequent cleavage stage embryos (Rosner et al. 1990, Schöler et al. 1990, Palmieri et al. 1994), while in the expanded murine blastocyst stage both mRNA and protein were predominantly found in the ICM (Palmieri et al. 1994, Pesce et al. 1998, Kirchof et al. 2000). However, even in fully expanded bovine and porcine blastocysts, both ICM and trophectoderm cells were found to be positive for Oct-4 protein (Kirchof et al. 2000). The quantitative expression profiling results throughout the preimplantation embryonic stages in the present study evidenced that Oct-4 is activated from both maternal and embryonic genome. Transcript abundance sharply increases after maturation 
and down-regulated until the four-cell stage. A higher level of Oct- 4 transcript abundance at the matured oocyte stage was accompanied by the presence of a maternal protein product as confirmed by Western blot analysis (Fig. 8). This shows that Oct-4 is activated from both maternal and embryonic genome during bovine embryogenesis. The detectable amount of Oct-4 transcript was very low between the eight-cell and morula stages, after which it is up-regulated at the blastocyst stage. Therefore, injection of Oct- 4 dsRNA is targeting transcripts which are starting the minor embryonic activation at the two- to four-cell stages and in the major embryonic activation after the 16-cell stage. Consequently, injection of Oct-4 dsRNA at the zygote stage has resulted in a $72 \%$ reduction at the blastocyst stage compared with the uninjected controls. Despite slight variations in the relative abundance of Oct-4 transcript between the water-injected group and uninjected control group, differences are not significant. Similar studies in mouse have reported that suppression of about $90 \%$ has been achieved using sequence specific dsRNA (Svoboda et al. 2004).

Oct-4 as transcription factor protein is known to bind to DNA and activate or repress transcription of several genes expressed during early embryonic development (Shin et al. 2005). In the present study, suppression of Oct-4 transcript in bovine embryogenesis using dsRNA has resulted in co-suppression of Fgf-4 gene at a level of $70 \%$, while the transcript remained unaffected in the water-injected group and uninjected controls. This is in agreement with the observation made in Oct- $4^{-1-}$ mouse embryos, where Fgf- 4 transcript abundance has been reduced (Nichols et al. 1998). Moreover, the expression of Fgf-4 transcript was found to be downregulated after targeted suppression of Oct-4 using siRNA expression vector in mouse (Haraguchi et al. 2004). The Fgf-4 gene is an octamer-containing enhancer in its $3^{\prime}$ noncoding region and has been demonstrated to respond to Oct-4 gene (Yuan et al. 1996, Ambrosetti et al. 1997, Daniels et al. 2000). Studies in mouse have shown that this gene is coexpressed with Oct- 4 in the ICM and epiblast (Ma et al. 1992, Niswander \& Martin 1992). Recently, the effect of down-regulation of Oct-4 transcript using dsRNA on the expression of other genes in mouse embryos has been investigated using annealing control primer technique (Shin et al. 2005) whereby, of the ten genes, eight (Atp6ap2, GK003, Ddb1, hRscp, Dppa1, Dpp3, Sap18, and Rent1) were down-regulated and two (Rps14 and ETIF2B) were up-regulated in Oct-4 dsRNAinjected blastocysts. The specificity of Oct- 4 dsRNA on targeted mRNA has been investigated by quantitative expression analysis of another blastocyst transcript (E-cadherin) and a house-keeping gene $(\mathrm{H} 2 \mathrm{a})$.

We have demonstrated that degradation of Oct-4 mRNA resulted in consequent reduction in protein synthesis and in developmental aberrations. Oct-4
dsRNA injection has affected the cleavage rate of zygotes to develop to the two-cell stage. Even though the day 5 morula rate was lower in the Oct-4 dsRNA-injected group compared to the water-injected group and uninjected controls, these differences were not significant. In order to investigate the effect of Oct-4 suppression on the rate of embryo development, we have investigated the blastocyst rate from day 6 to day 8 . Most of the blastocysts from Oct-4 dsRNA-injected groups appeared at days 7 and 8 while only few blastocysts were found at day 6 of development. However, a comparable developmental rate with respect to blastocysts rate between day 6 and day 8 has been observed in the water-injected group and uninjected controls. The overall blastocyst rate was lower in Oct-4 dsRNA-injected embryos compared to the waterinjected group and uninjected controls but differences are not significant. While the Oct- $4^{-/-}$mouse showed a post-implantation lethality before egg cylinder formation, Oct-4-deficient mouse embryos developed normally up to blastocyst stage but the ICM were not pluripotent and divert to a trophoblast fate when placed in embryonic stem cell culture conditions (Nichols et al. 1998). Marked differences have been observed in Oct-4 mRNA and protein expression in murine and bovine species (Kirchof et al. 2000). As opposed to the study in mouse where Oct- 4 expression is correlated with the undifferentiated cell types, suggesting that Oct- 4 is a marker for pluritency and its expression is restricted to ICM (Ovitt \& Schöler 1998), the Oct-4 protein was detected in both ICM and trophectoderm cells of murine and bovine expanded blastocysts, indicating that it may be the biological activity of the Oct-4, and not simply its presence, that correlates with the embryonic stem cell type (Kirchof et al. 2000).

In the present study, Oct-4 dsRNA-injected zygotes resulted in blastocysts of lower cell number compared to the water-injected group and uninjected controls. This was significantly evident in the number of ICM cells which were found to be reduced due to down-regulation of Oct-4 transcript. The optimal level of Oct-3/4 is reported to determine the fate of embryonic stem cells (Niwa et al. 2000), in which less than a twofold increase from the normal expression level causes differentiation into ectoderm and mesoderm, whereas a lower level leads to dedifferentiation into trophectoderm. However, due to absence of differences in the number of TE cells between the three groups, migration of cells to TE cells cannot be evidenced in the present study.

In conclusion, the present study has evidenced the use of sequence specific C-mos and Oct- 4 dsRNA to induce RNAi in bovine oocytes and embryos, respectively, to suppress maternal or embryonic transcripts leading to subsequent reduction in functional protein expression and result in a distinct developmental phenotype with respect to oocyte maturation, the rate 
of embryonic development and cell number of the resulting blastocysts.

\section{Acknowledgements}

The authors declare that there is no conflict of interest that would prejudice the impartiality of this scientific work.

\section{References}

Alizadeh Z, Kageyama S \& Aoki F 2005 Degradation of maternal mRNA in mouse embryos: selective degradation of specific mRNAs after fertilization. Molecular Reproduction and Development 72 281-290.

Ambrosetti DC, Basilico C \& Dailey L 1997 Synergistic activation of the fibroblast growth factor 4 enhancer by Sox 2 and Oct-3 depends on protein interactions facilitated by a specific spatial arrangement of factor binding sites. Molecular and Cellular Biology 17 6321-6329.

Araki K, Naito K, Haraguchi S, Suzuki R, Yokoyama M, Inoue M, Aizawa S, Toyoda Y \& Sato E 1996 Meiotic abnormalities of c-mos knockout mouse oocytes: activation after first meiosis or entrance into third meiotic metaphase. Biology of Reproduction 55 1315-1324.

Brizuela L, Draetta G \& Beach D 1989 Activation of human CDC2 protein as a histone $\mathrm{H} 1$ kinase is associated with complex formation with the p62 subunit. PNAS 86 4362-4366.

Brusselmans K, De Schrijver E, Verhoeven G \& Swinnen JV 2005 RNA interference-mediated silencing of the acetyl-CoA-carboxylasealpha gene induces growth inhibition and apoptosis of prostate cancer cells. Cancer Research 65 6719-6725.

Cabot RA \& Prather RS 2003 Cleavage stage porcine embryos may have differing developmental requirements for karyopherins alpha2 and alpha3. Molecular Reproduction and Development 64 292-301.

Cheng TL, Chang WW, Su IJ, Lai MD, Huang W, Lei HY \& Chang WT 2005 Therapeutic inhibition of hepatitis B virus surface antigen expression by RNA interference. Biochemical and Biophysical Research Communications 336 820-830.

Colledge WH, Carlton MB, Udy GB \& Evans MJ 1994 Disruption of c-mos causes parthenogenetic development of unfertilized mouse eggs. Nature 370 65-68.

Daniels R, Halla V \& Trounsona AO 2000 Analysis of gene transcription in bovine nuclear transfer embryos reconstructed with granulosa cell nuclei. Biology of Reproduction 63 1034-1040.

Draetta G \& Beach D 1988 Activation of cdc2 protein kinase during mitosis in human cells: cell cycle-dependent phosphorylation and subunit rearrangement. Cell 54 17-26.

Elbashir SM, Martinez J, Patkaniowska A, Lendeckel W \& Tuschl T 2001 Functional anatomy of siRNAs for mediating efficient RNAi in Drosophila melanogaster embryo lysate. EMBO Journal 20 6877-6888.

El-Halawany N, Ponsuksili S, Wimmers K, Gilles M, Tesfaye D \& Schellander K 2005 Quantitative expression analysis of blastocystderived gene transcripts in preimplantation developmental stages of in vitro-produced bovine embryos using real-time polymerase chain reaction technology. Reproduction, Fertility and Development 16 753-762.

Ezashi T, Ghosh D \& Roberts RM 2001 Repression of Ets-2-induced transactivation of the tau interferon promoter by Oct-4. Molecular and Cellular Biology 21 7883-7891.

Fan HY \& Sun QY 2004 Involvement of mitogen-activated protein kinase cascade during oocyte maturation and fertilization in mammals. Biology of Reproduction 70 535-547.

Fire A 1999 RNA-triggered gene silencing. Trends in Genetics 15 358-363.
Fire A, Xu S, Montogomery MK, Kostas SA, Driver SE \& Mello CC 1998 Potent and specific genetic interference by double stranded RNA in Caenorhabditis elegams. Nature 391 806-811.

Fissore R, He CL \& Woude GFV 1996 Potential role of mitogenactivated protein kinase during meiosis resumption in bovine oocytes. Biology of Reproduction 55 1261-1270.

Goldman DS, Kiessling AA, Millette CF \& Cooper GM 1987 Expression of c-mos RNA in germ cells of male and female mice. PNAS $\mathbf{8 4}$ 4509-4513.

Gotoh Y \& Nishida E 1995 Activation mechanism and function of the MAP kinase cascade. Molecular Reproduction and Development 42 486-492.

Grabarek JB, Plusa B, Glover DM \& Zernicka-Goetz M 2002 Efficient delivery of dsRNA into zona-enclosed mouse oocytes and preimplantation embryos by electroporation. Genesis 32 269-276.

Gui LM \& Joyce IM 2005 RNA interference evidence that growth differentiation factor-9 mediates oocyte regulation of cumulus expansion in mice. Biology of Reproduction 72 195-199.

Haraguchi S, Saga Y, Naito K, Inoue H \& Seto A 2004 Specific gene silencing in the pre-implantation stage mouse embryo by an siRNA expression vector system. Molecular Reproduction and Development 68 17-24.

Hirao Y \& Eppig JJ 1997 Analysis of the mechanism(s) of metaphase I arrest in strain LT mouse oocytes: participation of MOS. Development 124 5107-5113.

Hyslop L, Stojkovic M, Armstrong L, Walter T, Stojkovic P, Przyborski S, Herbert M, Murdoch A, Strachan T \& Lako M 2005 Downregulation of NANOG induces differentiation of human embryonic stem cells to extraembryonic lineages. Stem Cells 23 1035-1043.

Kiessling AA \& Cooper GM 1989 The expression of oncogenes in mammalian embryogenesis. In Growth factor in mammalian development, pp 167-174. Eds IY Rosenblem \& S Heyner. Boca Raton: GRC Press.

Kirchof N, Carnwath JW, Lemme E, Anastassiadis K, Schöler H \& Niemann H 2000 Expression pattern of Oct-4 in preimplantation embryos of different species. Biology of Reproduction 63 1698-1705.

Kosako H, Gotoh Y \& Nishida E 1996 Multiple roles of the mitogenactivated protein kinase kinase/mitogen-activated kinase cascade in Xenopus laevis. Development, Growth and Differentiation 38 $577-582$.

Larue L, Ohsugi M, Hirchenhain J \& Kemler R 1994 E-cadherin null mutant embryos fail to form a trophectoderm epithelium. PNAS $\mathbf{9 1}$ 8263-8267.

Lazar S, Gershon E \& Dekel N 2004 Selective degradation of cyclin B1 mRNA in rat oocytes by RNA interference (RNAi). Journal of Molecular Endocrinology 33 73-85.

Lonergan P, Gutierrez-Adan A, Rizos D, Pintado B, de la Fuente J \& Boland MP 2003a Relative messenger RNA abundance in bovine oocytes collected in vitro or in vivo before and $20 \mathrm{hr}$ after the preovulatory luteinizing hormone surge. Molecular Reproduction and Development 66 297-305.

Lonergan P, Rizos D, Gutierrez-Adan A, Moreira PM, Pintado B, de la Fuente J \& Boland MP 2003b Temporal divergence in the pattern of messenger RNA expression in bovine embryos cultured from the zygote to blastocyst stage in vitro or in vivo. Biology of Reproduction 69 1424-1431.

Ma YG, Rosfjord E, Huebert C, Wilder P, Tiesman J, Kelly D \& Rizzino A 1992 Transcriptional regulation of the murine k-FGF gene in embryonic cell lines. Developmental Biology 154 45-54.

Ma J, Zhou H, Su L \& Ji W 2002 Effect of exogenous double-stranded RNA on the basonuclin gene expression in mouse oocytes. Science in China Series C 45 593-603.

Masui Y 1992 Towards understanding the control of the division cycle in animal cells. Biochemistry and Cell Biology 70 920-945.

Memili E \& First NL 2000 Zygotic and embryonic gene expression in cow: a review of timing and mechanisms of early gene expression as compared with other species. Zygote 8 87-96. 
Motlik J \& Kubelka M 1990 Cell-cycle aspects of growth and maturation of mammalian oocytes. Molecular Reproduction and Development 27 366-375.

Mutter G \& Wolgemuth DJ 1987 Distinct developmental patterns of cmos proto-oncogen expression in female and male mouse germ cells. PNAS 84 5301-5305.

Nganvongpanit K, Muller H, Rings F, Gilles M, Jennen D, Holker M, Tholen E, Schellander K \& Tesfaye D 2006 Targeted suppression of E-cadherin gene expression in bovine preimplantation embryo by RNA interference technology using double-stranded RNA. Molecular Reproduction and Development 73 153-163.

Nichols J, Zevnik B, Anastassiadis K, Niwa H, Klewe-Nebenius D, Chamners I, Scholer H \& Smith A 1998 Formation of pluripotent stem cells in the mammalian embryo depends on the POU transcription factor Oct4. Cell 95 379-391.

Niswander L \& Martin GR 1992 Fgf-4 expression during gastrulation, myogenesis, limb and tooth development in the mouse. Development 114 755-768.

Niwa H, Miyazaki J \& Smith AG 2000 Quantitative expression of Oct-3/4 defines differentiation, dedifferentiation or self-renewal of ES cells. Nature Genetics 24 372-376.

Ohashi S, Naito K, Sugiura K, Iwamori N, Goto S, Naruoka H \& Tojo H 2003 Analyses of mitogen-activated protein kinase function in the maturation of procine oocytes. Biology of Reproduction $\mathbf{6 8}$ 604-609.

Okamoto K, Okazawa H, Okuda A, Sakai M, Muramatsu M \& Hamada H 1990 A novel octamer binding transcription factor is differentially expressed in mouse embryonic cells. Cell 60 461-472.

Ovitt CE \& Schöler HR 1998 The molecular biology of Oct-4 in the early mouse embryo. Molecular Human Reproduction 4 1021-1031.

Pal SK, Torry D, Serta R, Crowell RD, Siebel MM, Cooper GM \& Kiessling AA 1994 Expression and potential function of the c-mos proto-oncogene in human eggs. Fertility and Sterility 61 496-503.

Palmieri SL, Peter W, Hess H \& Schöler HR 1994 Oct-4 transcription factor is differentially expressed in the mouse embryo during establishment of the first two extraembryonic cell lineages involved in implantation. Developmental Biology 166 259-267.

Paradis F, Vigneault C, Robert C \& Sirard M-A 2005 RNA interference as a tool to study gene function in bovine oocytes. Molecular Reproduction and Development 70 111-121.

Parrish J, Susko-Parrish J, Leibfried-Rutledge ML, Critser ES, Eyestone WH \& First NL 1988 Bovine in vitro fertilization with frozen thawed sperm. Theriogenology 25 591-600.

Pesce M \& Schöler HR 2001 Oct-4: gatekeeper in the beginnings of mammalian development. Stem Cells 19 271-278.

Pesce M, Wang X, Wolgemuth DJ \& Schöler HR 1998 Differential expression of the Oct-4 transcription factor during mouse germ cell differentiation. Mechanisms of Development 71 89-98.

Plusa B, Frankenberg S, Chalmers A, Hadjantonakis AK, Moore CA, Papalopulu N, Papaioannou VE, Glover DM \& Zernicka-Goetz M 2005 Downregulation of Par3 and aPKC function directs cells towards the ICM in the preimplantation mouse embryo. Journal of Cell Science 118 505-515.

Riethmacher D, Brinkmann V \& Birchmeier C 1995 A targeted mutation in the mouse E-cadherin gene results in defective preimplantation development. PNAS 92 855-859.

Rizos D, Lonergan P, Boland MP, Arroyo-Garcia R, Pintado B, de la Fuente J \& Gutierrez-Adan A 2002 Analysis of differential messenger RNA expression between bovine blastocysts produced in different culture systems: implications for blastocyst quality. Biology of Reproduction 66 589-595.

Rizos D, Gutierrez-Adan A, Perez-Garnelo S, De La Fuente J, Boland MP \& Lonergan P 2003 Bovine embryo culture in the presence or absence of serum: implications for blastocyst development, cryotolerance, and messenger RNA expression. Biology of Reproduction 68 236-243.

Robert C, McGraw S, Massicotte L, Pravetoni M, Gandolfi F \& Sirard MA 2002 Quantification of housekeeping transcript levels during the development of bovine preimplantation embryo. Biology of Reproduction 67 1465-1472.

Rosner MH, Vigano MA, Ozato K, Timmons PM, Poirier F, Rigby PW \& Staudt LM 1990 A POU-dom main transcription factor in early stem cells and germ cells of the mammalian embryo. Nature $\mathbf{3 4 5}$ 686-692.

Sagata N 1996 Meiotic metaphase arrest in animal oocytes: its mechanisms and biological significance. Trends in Cell Biology $\mathbf{6}$ $22-28$.

Sagata N, Oskarsson M, Copeland T, Brumbaugh J \& Vande Woude GF 1988 Function of c-mos proto-oncogene product in meiotic maturation in Xenopus oocytes. Nature 335 516-525.

Schöler HR, Dressler GR, Balling R, Rohdewohld H \& Gruss P 1990 Oct-4: a germline-specific transcription factor mapping to the mouse t-complex. EMBO Journal 9 2185-2195.

Shin MR, Cui XS, Jun JH, Jeong YJ \& Kim NH 2005 Identification of mouse blastocyst genes that are downregulated by double-stranded RNA-mediated knockdown of Oct-4 expression. Molecular Reproduction and Development 70 390-396.

Siddall LS, Barcroft LC \& Watson AJ 2002 Targeting gene expression in the preimplantation mouse embryo using morpholino antisense oligonucleotides. Molecular Reproduction and Development 63 413-421.

Stein P, Svoboda P \& Schultz RM 2003 Transgenic RNAi in mouse oocytes: a simple and fast approach to study gene function. Developmental Biology 256 187-193.

Svoboda P 2004 Long dsRNA and silent genes strike back: RNAi in mouse oocytes and early embryos. Cytogenetic and Genome Research 105 422-434.

Svoboda P, Stein P, Hayashi H \& Schultz RM 2000 Selective reduction of dormant maternal mRNA in mouse oocytes by RNA interference. Development 127 4147-4156.

Svoboda P, Stein P, Anger M, Bernstein E, Hannon GJ \& Schultz RM 2004 RNAi and expression of retrotransposons MuERV-L and IAP in preimplantation mouse embryos. Developmental Biology 269 276-285.

Tesfaye D, Ponsuksili S, Wimmers K, Gilles M \& Schellander K 2004 A comparative expression analysis of gene transcripts in postfertilization developmental stages of bovine embryos produced in vitro or in vivo. Reproduction in Domestic Animals 39 396-404.

Wianny F \& Zernicka-Goetz M 2000 Specific interference with gene function by double-stranded RNA in early mouse development. Nature Cell Biology 2 70-75.

Wu B, Ignotz G, Currie WB \& Yang X 1997 Expression of most protooncogene in bovine oocytes during maturation in vitro. Biology of Reproduction 56 260-265.

Xu Z, Williams CJ, Kopf GS \& Schultz RM 2003 Maturation-associated increase in IP3 receptor type 1: role in conferring increased IP3 sensitivity and $\mathrm{Ca} 2+$ oscillatory behavior in mouse eggs. Developmental Biology 254 163-171.

Yuan H, Corbi N, Basilico C \& Dailey L 1996 Developmental-specific activity of the FGF-4 enhancer requires the synergistic action of Sox2 and Oct-3. Genes and Development 9 2635-2645.

Received 11 November 2005

First decision 23 December 2005

Revised manuscript received 30 January 2006

Accepted 7 February 2006 